\title{
Design of an instrument to measure Environmental Quality
}

\section{Diseño de un instrumento para medir la Calidad Ambiental}

\author{
ALARCÓN-RUIZ, Erika †*1, ORDOÑEZ-PACHECO, Luis Daniel², RAMÍREZ-SALAS, Virginia ${ }^{1}$ \\ and AVILES-CONTRERAS, Areli Monserrat ${ }^{3}$

\begin{abstract}
${ }^{1}$ Instituto Tecnológico de Ciudad Madero / Tecnológico Nacional de México, Department of Chemical and Biochemical Engineering

${ }^{2}$ Instituto Tecnológico de Ciudad Madero/ Tecnológico Nacional de México, Department of Computer Systems Engineering

${ }^{3}$ Instituto Tecnológico de Ciudad Madero/ Tecnológico Nacional de México
\end{abstract}

ID 1" Author: Erika, Alarcón-Ruiz / ORC ID: 0000-0003-1375-3442, CVU CONACYT ID: 163514.

ID $1^{\text {st }}$ Coauthor: Luis Daniel, Ordoñez-Pacheco / ORC ID: 0000-0003-2262-7296, CVU CONACYT ID: 844011

ID $2^{\text {nd }}$ Coauthor: Virginia, Ramírez-Salas / CVU CONACYT ID: 173197

ID $3^{\text {rd }}$ Coauthor: Areli Monserrat, Aviles-Contreras

DOI: $10.35429 / J E S N .2020 .17 .6 .1 .6$

Received March 26, 2020; Accepted June 28, 2020

\begin{abstract}
The criteria for selecting the methods that allow the calculation of pollutant emissions, establish that monitoring and direct measurements are preferably carried out at the sources. The drawback lies in the high costs in time and money, the difficulty in accessing the sampling points and the need for a physical, technical and specialized human resources infrastructure. On the other hand, there are indirect methods based on emission factors, activity rates, estimation using historical data, material balance, engineering calculations and mathematical emission models. In this work, the design of an instrument to measure environmental quality is presented.
\end{abstract}

Environmental Quality, Indirect Techniques, Estimates

\section{Resumen}

Los criterios para seleccionar los métodos que permitan calcular las emisiones contaminantes, establecen que preferentemente se realicen monitoreos y mediciones directas a las fuentes. El inconveniente radica en los altos costos en tiempo y dinero, la dificultad para acceder a los puntos de muestreo y la necesidad de una infraestructura física, técnica y de recursos humanos especializados. Por otro lado, existen métodos indirectos basados en factores de emisión, tasas de actividad, estimación mediante datos históricos, balance de materiales, cálculos de ingeniería y modelos matemáticos de emisión. En este trabajo se presenta el diseño de un instrumento para medir la calidad ambiental.

Calidad Ambiental, Técnicas indirectas, Estimaciones

Citation: ALARCÓN-RUIZ, Erika, ORDOÑEZ-PACHECO, Luis Daniel, RAMÍREZ-SALAS, Virginia and AVILESCONTRERAS, Areli Monserrat. Design of an instrument to measure Environmental Quality. Journal of Environmental Sciences and Natural Resources. 2020, 6-17: 1-6

\footnotetext{
* Correspondence to Author (email: erika.ar@cdmadero.tecnm.mx)

$\dagger$ Researcher contributing first author.
} 


\section{Introduction}

An environmental factor is an environment or subsystem of the environment with its own dynamics and processes to which a set of indicators is assigned that allow it to evaluate the quality of the environment. The quality of the environment will be the result obtained from the sum of the qualities of the relevant environmental factors and their evolution (Martin, 2007), (Hernández Muñoz, Hernández Lehman, \& Gordillo Martínez, 2006).

There are different models of environmental quality analysis, but it should be noted that most of these methods were developed for specific projects, resulting in their complicated generalization.

General Systems Theory is presented as a systematic and scientific way of approaching and representing reality that is characterized by its holistic and integrative perspective. There are two main groups of strategies for research in general systems:

a. Detail the interdependence of the parts that make up the system and its parts.

b. Model the inputs and outputs through which the system interacts with its environment.

The environmental quality can be evaluated by means of indicators that serve to determine in an objective way the situation in the aspects that this concept contemplates. Generally, these are physical, chemical and biological vectors that are considered relevant according to the system or resource under investigation. These are some examples of indicators that can characterize environmental quality:

\section{In water:}

- Volume of drinking water consumed by industrial sector (thousands of $\mathrm{m} 3$ /year) Volume of domestic wastewater generated (thousands $\mathrm{m} 3$ /year).

- Volume of industrial wastewater generated (thousands $\mathrm{m} 3$ /year).

- Relationship between the volume of treated and untreated wastewater.
On air:

$\begin{array}{ll}- & \begin{array}{l}\text { Carbon dioxide }(\mathrm{CO} 2) \quad \text { emissions } \\ \left(\mathrm{ug} / \mathrm{m}^{3}\right)\end{array} \\ - & \text { Greenhouse gas emissions. } \\ -\quad & \text { CFC substitution (kilograms). } \\ -\quad & \text { Sulfur dioxide emissions }\left(\mathrm{ug} / \mathrm{m}^{3}\right) .\end{array}$

In soil:

- $\quad$ Total consumption of pesticides.

- Volume of solid waste collected (tons/year)

- Recycling of solid waste collected (thousands of tons/year).

- Population with access to waste collection (inhabitants).

\section{Computer tool development}

Technological tools arise as a product of the application of the scientific knowledge of the discipline in the construction of artifacts that are incorporated into the real or virtual world in the form of products or services. (Barchini, 2006).

Information and communication technologies (ICTs) are today fundamental in all areas of society and in the quest to care for the environment and help in natural disasters they are not left behind (INE, 2005); on the contrary, ICTs have established themselves as an essential factor in this area and this is how governments and civil society have understood it in the world. Environmental informatics integrates information technologies and environmental sustainability, contributing to the conservation of the environment, generating new knowledge and promoting the dissemination and popularization of scientific knowledge, favoring a change in the habits and behaviors of citizens for the benefit of our environment.

Computing is a body formed by a conceptual infrastructure and a technological building where hardware and software are materialized (Serna Arenas, 2010). Computer systems are artificial systems that emulate the behavior of natural systems. In order to be able to propose it, it is necessary to first develop a conceptual system (symbolic construction) that allows to abstract the portion of the reality of the problem to be solved. 
Table $\mathrm{x}$ shows a taxonomy of computer science based on the Association for Computing Machinery (ACM) (Association for Computing Machinery, 2012), (REMIDEC, 2008). This work covers the areas of artificial intelligence, software engineering, information systems and databases applied to the environment.

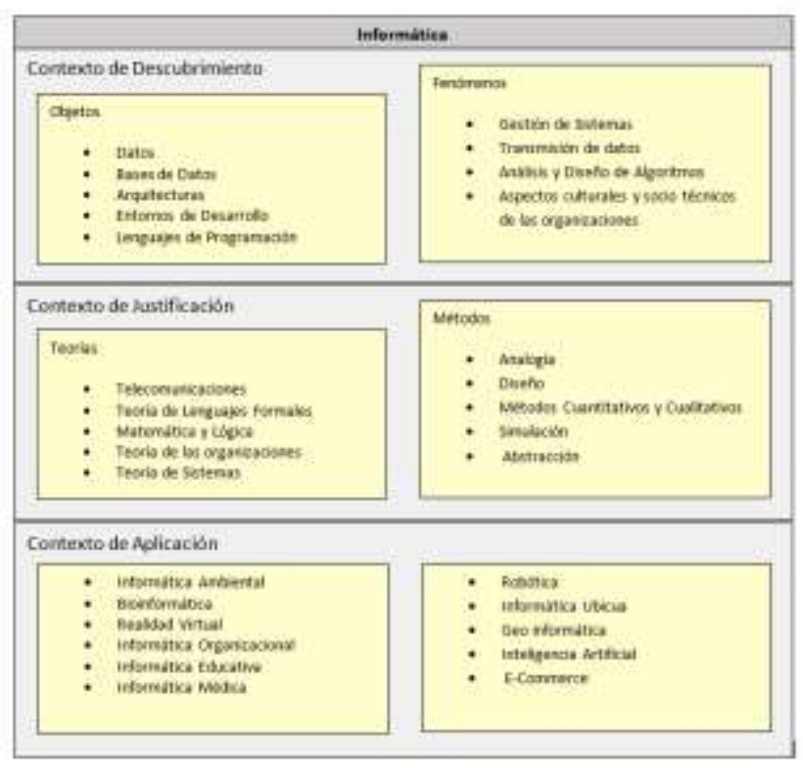

Figure 1 Application-synergetic interaction of computer science with other sciences

Environmental informatics integrates information technologies and environmental sustainability contributing to the conservation of the environment, generating new knowledge and promoting the dissemination and popularization of scientific knowledge favoring a change in the habits and behaviors of citizens for the benefit of our environment.

\section{Design of the instrument from indirect techniques of environmental quality estimation}

The criteria for selecting the methods that allow for the calculation of contaminating emissions, establish that preferably direct monitoring and measurements of the sources should be carried out, the inconvenience lies in the high costs in time and money, the difficulty in accessing the sampling points and the need for specialized physical, technical and human resource infrastructure (Gordillo et al. 2010) On the other hand, there are indirect methods based on emission factors, activity rates, estimation through historical data, material balance, engineering calculations and mathematical emission models (INE 2005).
The Rapid Assessment of Environmental Pollution Sources (ERFCA) technique is an indirect environmental quality estimation technique designed by the WHO, which, although it is a very consistent methodological instrument developed for countries with a lack of economic resources and a lack of reliable databases, needs to be systematized in order to facilitate the handling of large amounts of information that have served as the basis for the development of other indirect techniques.

\section{The Rapid Assessment Procedure}

The proposed rapid assessment methodology allows for effective evaluation of air pollution emissions generated by each source or groups of similar sources within a given study area. It also allows for the evaluation of the effectiveness of alternative pollution control options. This method is based on previous documented experiences on the nature and quantity of pollutants generated by each type of source, either with or without control systems, and makes constant use of this information to predict the loads of a given source.

The advantages of the rapid assessment approach include the convenience of use, which allows comprehensive inventories of air pollution sources to be made in highly complex situations, in just a few weeks and with few resources. Another major advantage of the method is that it allows the effectiveness of alternative control schemes to be properly estimated in relation to their potential to reduce the pollution load.

On the other hand, the advances in information and telecommunication technologies have favored the studies in environmental matters carried out by different research groups, allowing the consolidation of strategies that allow the integration of information in such a way that it has a meaning and is accessible from any place. Therefore, the general architecture of the environmental quality assessment system is based on the client-server model and it is proposed that the integration of relevant information generated in other environmental information systems be integrated through an ontology that allows the conceptualization of environmental problems from a computerized point of view and that integrates as much as possible the available information as shown in Figure 2.

ALARCÓN-RUIZ, Erika, ORDOÑEZ-PACHECO, Luis Daniel, RAMÍREZ-SALAS, Virginia and AVILES-CONTRERAS, Areli Monserrat. Design of an instrument to measure Environmental Quality. Journal of Environmental Sciences and Natural Resources. 2020 


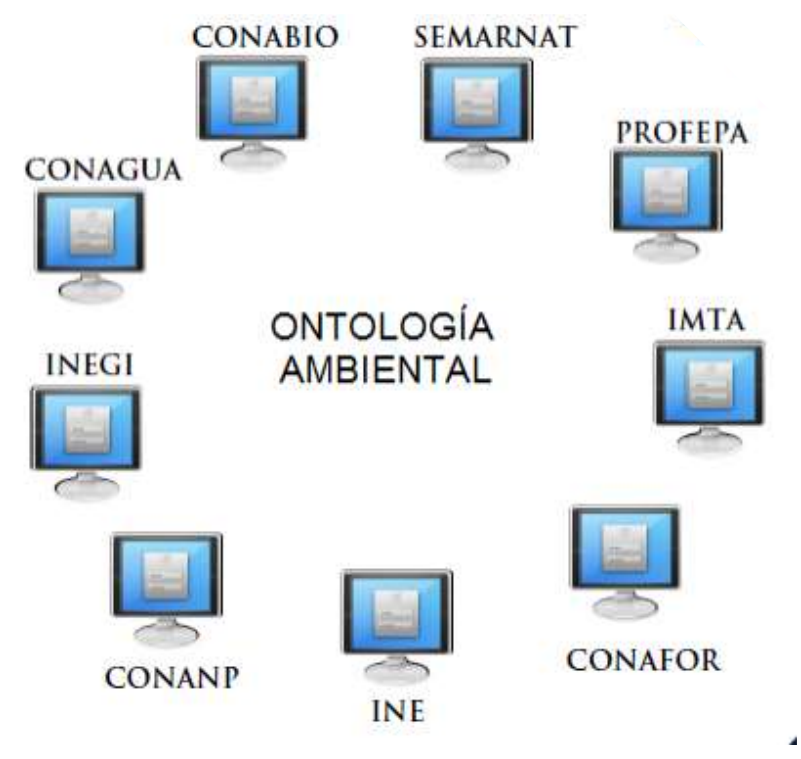

Figure 2

\section{Structure of the list of possible data sources}

The ERFCA technique, lists a list of possible data sources that are necessary for the calculations, the reliability of the final report much depends on the quality of the data collected so it is essential to point out the source of data collection and source of verification as indicated in table 1.

The following is the structure of the list of possible data sources.

\begin{tabular}{|l|l|}
\hline \multicolumn{2}{|c|}{ Data type } \\
\multicolumn{1}{|c|}{ Sossible } \\
\hline Population & INEGI \\
\hline Health, Mortality and Morbidity & INEGI \\
\hline Climatological & INE \\
\cline { 2 - 2 } & CONAGUA \\
\hline Hydrological data & INEGI \\
\hline Agricultural activities & INEGI \\
\hline Mining Activity & INEGI \\
\hline Industrial activity & INEGI \\
\hline Industrial Processes & INEGI \\
\hline Road traffic data & INEGI \\
\hline Length of streets, roads and highways & INEGI \\
\hline Airport activity data & INEGI \\
\hline Data on port activities & INEGI \\
\hline Fuel consumption data & INEGI \\
\hline Fuel quality & INEGI \\
\hline Water supply & INEGI \\
\hline Waste collection and disposal & INEGI \\
\hline Solid Waste Facts & INEGI \\
\hline $\begin{array}{l}\text { Water quality data and effluent load } \\
\text { data }\end{array}$ & INEGI \\
\hline Air quality and emission data & INEGI \\
\hline
\end{tabular}

Table 1 GIS information modeling

\section{Definition of the area of study}

Conducting a rapid assessment study at the national level is a complex task, so it is necessary to determine as a first step the study area or sets of study areas to be analyzed. Each study area is delimited by physical, political/legal and economic boundaries. In this paper we analyze the study areas delimited by political/legal boundaries such as the political division of municipalities.

The problem of defining the study zone and the importance of the data structures that store this information and the algorithmic complexity, key elements to determine the necessary programming tools and data warehouses, are addressed below.

Among the aspects to be considered to divide a study zone is the existence of several authorities or regulations such as state or municipal entities for the control of waste, so it has been considered to establish as a minimum unit of study zone the municipality (from the Latin municipium) which includes the territory (defined by legislation) and the population living in it and living in the same jurisdictional term governed by a municipality.

reliability $=\frac{\text { DataVerified }}{\text { Dataconsulted }}$

\section{Where Verified Data $\leq$ DataConsulted}

\section{Waste and pollution generating activities}

There are many types of pollution-generating activities in a study area. However, in order to make a rapid assessment, important sources such as power plants, steel mills and municipal water discharges must be highlighted. This work focuses on the sources of air, water and soil pollution in urban areas and industrial zones.

Through the National Institute of Statistics, Geography and Informatics (INEGI), it provides a unique, consistent and updated framework for the collection, analysis and presentation of economic statistics, which reflects the structure of the Mexican economy. Table 2 Divisions of manufacturing activity. 


\begin{tabular}{|l|l|}
\hline \multicolumn{2}{|c|}{ Key } \\
\hline 11 & Agricultural Production. \\
\hline 31 & Food, beverage and tobacco manufacturing. \\
\hline 32 & $\begin{array}{l}\text { Manufacture of textiles, clothing and leather } \\
\text { industry. }\end{array}$ \\
\hline 33 & $\begin{array}{l}\text { Manufacture of wood, wood products, including } \\
\text { furniture. }\end{array}$ \\
\hline 34 & $\begin{array}{l}\text { Paper manufacturing, paper products, printing and } \\
\text { publications. }\end{array}$ \\
\hline 35 & $\begin{array}{l}\text { Manufacture of chemicals, oil, coal, rubber and } \\
\text { plastic products. }\end{array}$ \\
\hline 36 & $\begin{array}{l}\text { Manufacture of non-metallic mineral products, } \\
\text { except petroleum products and coal. }\end{array}$ \\
\hline 37 & Basic metal industry. \\
\hline 38 & $\begin{array}{l}\text { Manufacture of manufactured metal products, } \\
\text { machinery and equipment. }\end{array}$ \\
\hline 39 & Other manufacturing industries. \\
\hline
\end{tabular}

\section{Calculations}

The indirect calculation to make an estimation of pollutant loads used by this technique, is based on the following foundation:

The total pollutant load $(\mathrm{K})$ received by the environment is the sum of the partial contributions of the different emission sources, as shown in equation 1 .

$K=\sum_{i=1}^{n} K_{i}$

Where:

$K_{i}=$ pollutant contribution of the emitting source $i$ $n=$ total number of broadcast sources

On the other hand, each pollutant source discharges several types of substances into the atmosphere (ec. 2).

$K_{i}=\sum_{j=1}^{m} K_{i j}$

Where:

$K_{i j}=$ contribution of pollutant $j$ from emission source $i$ $m=$ total number of pollutant types

Therefore, in the end you will have (ec. 3):

$$
K=\sum_{i=1}^{n} \quad \sum_{j=1}^{m} K_{i j}
$$

Using the information provided by each source of contamination, it can be grouped in a different way, according to interest, for a more globalized presentation. Previously, the case of total pollutants by source (Ki) was already indicated. The total of pollutant $\mathrm{j}$, provided by the different sources, could be of interest. In this case the following expression would be used (ec. 4):

$$
\mathbf{K}_{\mathrm{j}}=\sum_{\mathrm{i}=1}^{\mathbf{n}} \mathbf{K}_{\mathrm{ij}}
$$

Where: $\mathrm{Kj}=$ total contribution of pollutant $\mathrm{j}$ from $n$ sources

A first approximation to quantify the pollutant load that the environment receives, when real contribution studies have not yet been made, is made using contribution factors that for the different emission sources are recorded in the technical literature. In these cases it is assumed that the emission is a linear function of the production volume in the case of industries, or the amount of fuel used or consumed in the case of energy generating sources, and in general raw material burned. This can be expressed as follows (ec. 5):

$$
\mathrm{K}_{\mathrm{ij}}=\mathrm{F}_{\mathrm{ij}} \cdot \mathrm{P}_{\mathrm{i}}
$$

Where:

Fij $=$ emission factor of pollutant $\mathrm{j}$ from source i

$\mathrm{Pi}=$ production or consumption of source $\mathrm{i}$

Therefore the total contribution of source i will be (ec. 6):

$$
\mathrm{K}_{\mathrm{i}}=\sum_{\mathrm{j}=\mathrm{i}}^{m} \mathrm{~K}_{\mathrm{ij}} \underset{j=i}{=\sum_{j=i}^{m} \mathrm{~F}_{i j}} \cdot P_{i}=P_{i} \underset{j=i}{m} F_{i j}
$$

Para determinar las cantidades de contaminantes generados, se aplicaron los factores de emisión, agrupados en el caso industrial de acuerdo a sus diferentes actividades o giros manufactureros. Los protocolos distinguen entre aire, agua y suelo, considerando distintos indicadores ambientales en cada caso. De esta forma, se podría, establecer el destino y los ciclos de vida de residuos y de productos desechados y con ello conocer cuál es el sitio de disposición final de los contaminantes, situación que hasta la fecha es incierta. Para la presentación de los resultados se ha dispuesto de un conjunto de reportes a partir de los cuales se genera un conjunto de mapas temáticos que nos permitirán expresar de manera gráfica la relación o densidad de los contaminantes, tipos de medios y empresas de la zona de estudio y contrastarlos contra los índices permisibles de calidad ambiental en agua, suelo y aire. 


\section{Conclusions}

The rapid assessment procedure described above is extremely useful for making an initial evaluation of sources and emission levels in an area that has little or no data on pollution loads. It is also useful for selecting priority areas when more extensive monitoring is conducted; for conducting case studies as part of public health programs aimed at pollution control; and for formulating pollution control policies and regulations as part of national environmental health activities.

\section{References}

Arce R., Rosa M. (2007). Las tecnologías de información y las comunicaciones y el medioambiente. EOI escuela de Negocios. Fundación Gas Natural. Barcelona, España. ISBN-13: 978-84-611-5868-3.

Association for Computing Machinery, I. (2012). The ACM Computing Classification System. Publications Dept., ACM, Inc., http://www.acm.org/about/class/ccs98-html.

Barchini, Graciela E. 2006 Informática una disciplina bio-psico-socio-tecno-cultural. Universidad Nacional de Santiago del Estero, Argentina. Revista Ingeniería Informática, Edición 12, abril

Gordillo Martínez Alberto José, Cabrera Cruz René Bernardo Elías*, Hernández Mariano Marisol, Galindo Erick, Otazo Elena y Prieto Francisco (2010). Evaluación regional del impacto antropogénico sobre aire, agua y suelo. Caso: Huasteca Hidalguense, México. Rev Int Contam Ambient. (México) (ISSN: 0188-4999) Vol.26 (3) 229-251.

INE (2005). Registro de emisiones y transferencia de Contaminantes. Propuesta Ejecutiva Nacional. México. INESEMARNAP, en cooperación con el Instituto de las Naciones Unidas para la Capacitación e Investigación, México D.F., 162 p.

REMIDEC. (2008). Red Mexicana de Investigación y Desarrollo en México. Obtenido de http://turing.iimas.unam.mx/ remidec/manifiest o/adhman.php
Serna Arenas, A. (2010). Línea del tiempo de las ciencias computacionales. Revista Digital Lámpsakos, 86-94. 